\title{
TREND CIVITAS AKADEMIKA UIN SUNAN KALIJAGA DALAM MEMBAYAR ZAKAT
}

\author{
Zulkipli Lessy \\ UIN Sunan Kalijaga Yogyakarta \\ zulkifid@yahoo.com
}

\begin{abstract}
Empowerment of the poor is a long run program. Modern zakat institution is one of the zakat managements to have long run programs than the mosque takmir. As academicians, lectures and professors at UIN Sunan Kalijaga knew the existence and performance of modern zakat management. The research was aimed to explore zakat payment trends conducted by the lecturers and professors. First, the attitude of those lecturers and professors in giving their zakat either fitrah or maal; whether the payment was done by giving direct cash to zakat institutions or to mustahiq and the mosque takmir. Second, reasons that lay beyond choosing the payment methods. The results indicated the respondents tended to conserve the traditional method in giving zakat to the poor and the mosque. From 95 respondents surveyed, fifty five respondents paid their zakat fitrah and maal directly to individuals because they witness living poor individuals in their neighboorhood, and fourty respondents chose the modern method. And, from 95 respondents, twelve of the did not trust zakat institutions. Therefore, they paid their zakat directly to the poor.
\end{abstract}

Keywords: Trend, zakat, institution, mosque, individual.

\begin{abstract}
Abstrak
Pemberdayaan masyarakat miskin merupakan program jangka panjang. Rumah Zakat merupakan salah satu pengelola zakat yang memiliki program jangka panjang dalam pemberdayaan masyarakat miskin dibandingkan dengan takmir masjid yang kebanyakan tidak memiliki program pemberdayaan berjangka panjang. Sebagai kalangan terdidik, civitas akademika UIN Sunan Kalijaga tentu tahu keberadaan dan sepak terjang lembaga-lembaga pengelola zakat profesional. Penelitian ini mengeksplorasi kecenderungan pembayaran zakat dilakukan oleh civitas akademika UIN Sunan Kalijaga. Pertama, perilaku civitas akademika ini dalam membayar zakat baik fitrah maupun maal; apakah pembayaran itu dilakukan dengan membayar ke lembaga-lembaga pengelola zakat atau pembayaran itu dilakukan dengan membayar zakat langsung ke mustahiq atau takmir masjid. Kedua, alasan civitas akademika tersebut dibalik pemilihan metode pembayaran zakat. Hasil mengindikasikan bahwa responden cenderung bertahan dengan cara-cara tradisional dalam membayar zakat, yaitu pembayaran langsung kepada orang miskin atau masjid. Dari 95 responden, limapuluh lima orang membayar zakat fitrah dan maal secara langsung ke individu karena mereka menyaksikan langsung ada orang-orang miskin di lingkungan mereka, sementara empatpuluh responden memilih metode modern pada lembaga-lembaga pengelola zakat. Dari 95 responden itu, duabelas responden tidak mempercayai lembaga-lembaga pengelola zakat. Untuk itu, mereka memberi zakat langsung kepada orang miskin.
\end{abstract}

Kata kunci: Trend, zakat, lembaga, masjid, individu. 


\section{Pendahuluan}

Selama bertahun-tahun, zakat masih menjadi topik hangat untuk digali, diperdebatkan, dan diteliti pengelolaan dan kemanfaatannya. Hal ini terjadi karena kaum Muslim percaya bahwa zakat adalah salah satu media untuk mengurangi angka kemiskinan dan jalan untuk mensejahterakan masyarakat. Di kalangan perguruan tinggi Islam di Indoensia, penelitian tentang zakat telah banyak dilakukan. Objek yang diteliti pun bermacam-macam, antara lain tentang optimalisasi dana zakat, infaq dan sadaqah; ${ }^{1}$ juga tentang praktik pendistribusian zakat produktif pada BAZDA ${ }^{2}$ dan lain-lain. Hal yang membedakan penelitian ini dari penelitian lain adalah peneliti ini fokus pada trend pembayaran zakat yang dilakukan oleh civitas akademika UIN Sunan Kalijaga. Penelitian ini menarik dilakukan karena, sebagai kaum terpelajar, civitas akademika UIN Sunan Kalijaga tentu akan memilih untuk membayar zakat dengan cara-cara modern, misalnya, membayar zakat kepada lembaga-lembaga profesional pengelola zakat, seperti Dompet Duafa ataupun Rumah Zakat yang memiliki program jangka panjang untuk memberdayakan masyarakat miskin, dibandingkan dengan cara tradisional yaitu membayarkan zakat langsung kepada orang miskin ataupun takmir masjid yang kebanyakan belum memiliki program jangka dalam mengelola dana zakat untuk memberdayakan masyarakat miskin. Apakah civitas akademika UIN Sunan Kalijaga akan memilih untuk membayar zakat melalui cara-cara modern ataukah cara tradisional?

Sebagaimana telah diketahui selain bermakna penyucian, zakat juga berarti perkembangan. Zakat bermakna perkembangan artinya terdapat perputaran "harta" agar tidak hanya berpusat pada satu kelompok saja, tetapi bisa dirasakan oleh seluruh lapisan masyarakat.

1 M.S.N Aji, Optimalisasi Potensi Zakat, Infaq dan Shadaqah, Tesis, (Surakarta: UMS, 1999); Saifuddin, "Optimalisasi Distribusi Dana Zakat: Upaya Distribusi Kekayaan: Studi Terhadap UU No. 23 Tahun 2011 tentang Pengelolaan Zaka”t. Jurnal Az Zarqa, Vol 5, No 2, (Yogyakarta, Desember 2013).

${ }^{2}$ Emi Hartatik, “Analisis Praktik Pendistribusian Zakat Produktif Pada Badan Amil Zakat” 2015. 
Menurut Adnan, ${ }^{3}$ setiap tahun, umat Islam diwajibkan mengeluarkan zakat fitrah atau pemberian yang bersifat karitas. Kewajiban Muslim membayar donasi dalam bentuk zakat fitrah di penghujung Ramadan adalah sama dengan sejumlah uang dibelanjakan untuk makan sehari. Sebagai contoh, jika seseorang dalam satu hari menghabiskan biaya untuk makan sebesar Rp. 50.000, maka zakat yang dikeluarkan adalah sebesar Rp. 50.000. Berdasarkan pendapat tersebut, hal ini berarti besar atau kecilnya pengeluaran zakat disesuaikan dengan kebiasaan seseorang dalam mengalokasikan biaya untuk makan dalam sehari. Adapun Visser ${ }^{4}$ berpendapat jumlah zakat fitrah itu sebesar 2.5 kilogram makanan pokok. Zakat maal adalah pembayaran pajak kekayaan atau harta sebanyak 2.5 persen atas aset produktif yang telah melewati nishab dan haul. Dilihat dari segi pemanfaatan, zakat maal dan fitrah bertujuan mengurangi kemiskinan apabila dikelola secara efektif.

Dilihat dari segi populasi Muslim di seluruh dunia, Indonesia menempati peringkat nomor satu. Dengan jumlah populasi Muslim yang cukup banyak tersebut, Indonesia seharusnya dapat memanfaatkan potensi zakat yang dikeluarkan oleh umat Muslim. Doa menegaskan pemerintah Indonesia harus mempertimbangkan zakat sebagai sumber potensial bagi kesejahteraan sosial. Dari 240 juta penduduk Indonesia, 87 persen adalah Muslim, dan dari jumlah itu, 40 persen wajib mengeluarkan zakat karena hidup berkecukupan. ${ }^{5}$

Pengelolaan zakat saat ini telah mengalami perkembangan pesat dengan hadirnya lembaga-lembaga profesional yang mengelola zakat. Lembaga-lembaga tersebut antara lain BAZIZ, LAZIZ, Dompet Duafa, Rumah Zakat, atau LAZISMU. Kehadiran lembaga-lembaga profesional ini ternyata tidak menyurutkan langkah masyarakat untuk mengubah metode pembayaran dari tradisional dengan membayar langsung kepada mustahiq kepada cara-cara profesional dengan membayarkan melalui lembaga pengelola zakat.

\footnotetext{
${ }^{3}$ M.A. Adnan, (2011). "Accounting Treatment for Corporate Zakat: A Critical Review”, International Journal of Islamic and Middle Eastern Finance and Management, Vol 2, No 1, (2011), 32-45. 2011).

${ }^{4}$ H. Visser, Islamic Finance Principles and Practice, (Northampton, MA: Edward Elgar Publishing,

${ }^{5}$ Muhammad Daud Doa, Zakat Under the State Management, (Jakarta: Nuansa Madani, 2007).
} 
Penelitian ini telah menginvestigasi perilaku dosen dan pegawai administrasi Universitas Islam Negeri Sunan Kalijaga Yogyakarta berkaitan dengan penunaian zakat fitrah dan zakat maal. Melalui survey, responden telah ditanyai bagaimana motode pembayaran zakat yang mereka lakukan serta besaran zakat yang mereka keluarkan, apakah kewajiban zakat fitrah dan maal berkorelasi positif dengan metode dan jumlah pemberian, kepada siapa mereka memberikan zakat, berapa yang mereka berikan, serta apakah mereka memberikan zakat langsung ke individu atau melalui lembaga. Frekuensi mendatangi masjid, gender, umur, dan tingkat pendapatan juga ditanyakan.

\section{Permasalahan Zakat dan Anggapan yang Keliru terkait Zakat}

Wacana mengenai berapa banyak nilai zakat diberikan kepada mustahiq telah dijelaskan dalam syari'ah. Senturk (2009) menjelaskan harta yang wajib dikenai zakat adalah hewan ternak, harta bergerak dan tidak bergerak, barang tambang, hasil panen, atau barang dagangan. Sementara nishab untuk tiap jenis harta dan berapa zakat yang harus diambil dari itu bervariasi sesuai dengan statusnya. Muslim membayar zakat fitrah hanya sekali dalam setahun, sementara seorang Muslim membayar zakat maal apabila telah mencapai nishab. Wilson berpendapat zakat maal itu dikenai atas harta, seperti perak, emas, uang, hasil pertanian, perdagangan, atau harta lain yang bernilai. ${ }^{6}$ Powell $^{7}$ menjelaskan nishab harta adalah kurang dari lima uqiya perak (143.3 gram), lima unta, atau kurang dari lima wasq (180 kilogram) makanan. De Zayas berpendapat harga lima unta adalah unta yang dapat dimuati barang seberat 1568 kilogram. $^{8}$

${ }^{6}$ R. Wilson, “The Development of Islamic Economics: Theory and Practice.” In S. Taji-Farouki \& B.M. Sufi (Eds.). Islamic Thought in the Twentieth Century. (New York: St Martin's Press, 2006).

7 R. Powell, "Zakat: Drawing insights for Legal Theory and Economic Policy from Islamicc Jurisprudence." Retrieved from http://ssrn.com/abstract=1351024 in December, 2011.

${ }^{8}$ Faris G. De Zayas, The Law and Philosophy of Zakat: The Islamic Social Welfare System, (Damascus: Al-Jadidah Printing Press, 1962). 
Berdasarkan tipe harta, terdapat variasi nilai zakat. Misalnya, hasil panen dari ladang yang diirigasi, maka zakatnya adalah lima persen. Hasil panen dari ladang non-irigasi, maka zakatnya adalah 10 persen. Barang berharga terpendam yang ditemukan, tambang, dan mutiara dikenai zakat sekitar 20 persen. Selain ketiga jenis ini, kategori zakat maal tampak mewakili pendapatan masyarakat agraris yang bergantung pada hasil pertanian. Rata-rata zakat pada harta secara umum adalah 2.5 persen tergantung pada nilainya. Harta yang memiliki masa hidup pendek, seperti hewan ternak, mungkin berfungsi sebagai satu obyek penerimaan pajak, demikian juga dengan palawija. Barang-barang yang bertahan lama, seperti tanah, selalu berfungsi sebagai pajak kekayaan untuk mendorong dan menstimulasi investasi bisnis dan perdagangan.

Sesuai dengan keadaan geografis, tiap-tiap negara berbeda dalam menghitung nishab. Seorang petani Indonesia harus membayar zakat ketika berpenghasilan bersih sebesar dua juta rupiah. Pekerja kantor berdasi dan pekerja kasar harus membayar zakat maal ketika penghasilan bersih tersisa di akhir tahun sebesar tujuh juta rupiah. ${ }^{9}$ Namun dalam banyak kasus, masing-masing akan membayar sesuai dengan kemampuan. Secara tradisional, zakat itu sebagai kontribusi individu bagi masyarakat melalui lembaga-lembaga zakat atau secara langsung kepada yang membutuhkan, atau orang-orang miskin dan fakir. Untuk mengontrol dan mendistribusi zakat secara terpusat, pemerintah telah memobilisasi sumber-sumber melalui sarana-sarana publik dan menggunakan managemen pegawai negeri sebagai alat sejak 1960-an. ${ }^{10}$ Praktek modern menggunakan penggalangan institusi dan distribusi sumbersumber pribadi dan korporasi untuk meningkatkan kapasitas, menjaga kelangsungan pendanaan, dan keahlian untuk kesejahteraan masyarakat dalam jangka waktu panjang. Qatar, Arab Saudi, atau Pakistan telah memasukkan praktek pembayaran zakat sebagai pengurang pajak. Pakistan pada masa Presiden Zia ul-Haq telah memperkenalkan sistem penarikan zakat

${ }^{9}$ Faqih A. Kodir, Zakat Funds and Female Empowerment for Social Transformation. Dalam Hamid Abidin (Ed.). Reinterpretation of Effective Use of Zakat, infaq and shadaqah (pp. 85-100), (Jakarta: Piramedia, 2006).

${ }^{10}$ Public Interest Research \& Advocacy Center (PIRAC), Investing in Ourselves: Giving and Fund Raising in Indonesia, (Metro Manila: East Axis Creative, 2004). 
via pemotongan langsung melalui rekening bank ketika uang nasabah melebihi batas minimal. $^{11}$

Banyak Muslim salah anggapan bahwa yang ada hanya zakat fitrah, harus dibayarkan oleh Muslim yang mampu, sekali dalam setahun di akhir bulan Ramadan. Nilai minimum zakat fitrah itu 20.000 rupiah. Banyak Muslim tidak menyadari bahwa kewajiban zakat tidak hanya fitrah tetapi juga maal. Karena itu, banyak Muslim membayar zakat maal ditambahkan pada zakat fitrah di akhir tahun. Jumlah zakat maal, seperti telah didiskusikan, adalah 2.5 persen dari total harta dalam setahun. Kesalahan menafsirkan zakat semacam ini terjadi baik oleh Muslim Indonesia atau Muslim di negera-negara lain. Benthall melaporkan ketika Muslim Yordania mendengar kata "zakat", ia persepsikannya semata-mata zakat fitrah, bukan maal. Situasi ini biasa terjadi di kalangan Muslim Indonesia. Salah anggapan ini mungkin adalah penyebab utama mengapa target penerimaan zakat sebesar 14 triliun rupiah tidak pernah tercapai. $^{12}$

Salah seorang pembicara dari Dompet Dhuafa, dalam sebuah acara talkshow di sebuah televisi nasional, heran mengapa penerimaan zakat di Indonesia tidak pernah mencapai target. Secara ideal target harus tercapai mengingat jumlah Muslim yang mampu sebanyak 40 persen. Tetapi, aktualisasi penerimaan hanya kurang dari tiga persen dari target nasional. Ketika presenter acara bertanya mengapa Muslim Indonesia sulit membayar zakat fitrah yang hanya 25.000 rupiah, pembicara dari Dompet Dhuafa menjadi heran dengan pertanyaan ini karena rupanya presenter acara tidak menyadari bahwa Muslim pun harus membayar zakat maal, bukan hanya zakat fitrah yang besarannya minimal sekitar 25.000. Pertanyaan presenter membuat pembicara itu heran karena potensi zakat 14 triliun rupiah berasal bukan hanya dari zakat fitrah tetapi juga maal. Dari dialog ini, pembicara itu mulai menyadari bahwa potensi

11 G. Clark, "Pakistan's Zakat System: A Policy Model for Developing Countries as a Means of Redistributing Income to the Elderly Poor, Social Thought, Vol 20 No 3/4, (2003), 47-75.

12 Jonathan Benthall, (2001). Financial Worship: The Quranic Injunction to Alms-Giving, The Journal of the Royal Anthropological Institute, Vol 5 No 1, (2002), 27-42.

372 al-Maslahah: - Volume 12 Nomor 2 Oktober 2016 
zakat 14 triliun rupiah diperoleh dari pembayaran zakat fitrah, yaitu 20.000 rupiah sekali dalam setahun. ${ }^{13}$

Terdapat kecenderungan bahwa Muslim Indonesia memberikan zakat mereka utamanya berdasarkan simpati dan keinginan untuk bersedekah. Promosi yang dilakukan oleh lembaga-lembaga zakat tidak sampai pada estimasi target. Masyarakat mungkin berfikir yang wajib itu hanya fitrah karena promosi yang diinisiasi oleh lembaga-lembaga zakat hanya selama Ramadan. Salah anggapan ini, tentu saja, membutuhkan penelitian lanjut untuk mengkaji pemahaman masyarakat tentang petunjuk-petunjuk membayar zakat. Jika hipotesis ini benar, maka terjawab satu poin penting mengapa target 14 triliun rupiah itu tidak pernah tercapai. Apabila masyarakat memahami zakat hanya semata-mata fitrah, yaitu senilai 20.000 rupiah, dan bukan maal yang bernilai 2.5 persen, maka target yang diprediksikan itu hanyalah sebuah mimpi. Ini artinya bahwa realisasi kesejahteraan sosial melalui zakat sulit tercapai.

\section{Kajian Pustaka}

Pada masa awal Islam, zakat merupakan kewajiban bagi setiap Muslim. Aturan dan tata cara bagaimana zakat dikumpulkan dan didistribusikan berdasarkan pada syari'ah dan kebijakan para khalifah. Jenis pertama zakat, secara luas dikenal oleh Muslim adalah zakat fitrah, atau diterjemahkan sebagai pemberian bersifat personal, ditunaikan sebagai penyucian diri di akhir Ramadan. Nilai zakat fitrah itu sama dengan 2.5 kilogram dari makanan pokok seseorang atau ekuivalen dengan uang. Jenis yang kedua adalah zakat maal atau pajak harta, yang ditarik ketika donor memiliki harta dan telah melewati nishab. ${ }^{14}$ Dinasti Abbasiyah abad ke-10 Masehi memasukkan zakat dalam sistem perpajakan karena birokrasi pemerintahan membutuhkan anggaran untuk publik dan militer. Praktek semacam ini mengikuti praktek di masa awal Islam dan berkaitan dengan budaya Islam. ${ }^{15}$ Praktek ini juga mencakup jizya yang

13 Rahmat Riyadi, Kebijakan yang Wajib, Republika. Retrieved pada 2 Desember 2008 dari http://www.republika.cor.id.

${ }^{14}$ H. Visser, Islamic finance principles and practice, Northampton, MA: Edward Elgar Publishing, 2011).

${ }^{15}$ A. Hourani, A History of the Arab Peoples, (Cambridge: Harvard University Press, 1993). 
dibayarkan oleh non-Muslim yang hidup di bawah pemerintahan Islam. Namun, praktek zakat telah berubah dan menjadi pemberian sukarela sesuai dengan budaya lokal dan struktur politik. Setelah jatuhnya Turki Utsmani, praktek zakat telah mengalami kemunduran karena kolonialisasi di dunia Islam. Praktek zakat lalu menjadi praktek personal dimana pemerintah tidak mewajibkan zakat atas Muslim. Sebaliknya, pemerintah Muslim mengadopsi sistem perpajakan sekuler di waktu yang bersamaan. ${ }^{16}$

Kaum Muslim kini membayar zakat dalam dua cara: pertama, secara tradisional, mereka memberikan zakat langsung kepada orang-orang miskin dan yang membutuhkan, yayasan pendidikan, panti asuhan, atau masjid; kedua, kecenderungan terkini, kaum Muslim memberikan zakat via lembaga zakat. Salim menjelaskan sejak Indonesia bukan negara berdasarkan syari'ah, walaupun mayoritas penduduk adalah Muslim, negara tidak menghukum yang tidak membayar zakat. Tetapi, kaum Muslim paham bahwa zakat adalah kewajiban namun apabila tidak membayarnya mereka mungkin merasa berdosa karena tidak menyisihkan sebagian harta kepada yang membutuhkan. ${ }^{17}$

Muslim Indonesia berpandangan ganda menyangkut zakat; pertama, sebagian Muslim berpandangan zakat maal itu pilihan atau bahkan sistem ini tidak relevan karena telah ada sistem perpajakan modern. Akibatnya, banyak donasi karitas di Indonesia terbatas pada zakat fitrah yang berjumlah sedikit diberikan hanya di bulan Ramadan; kedua, beberapa mungkin memiliki persepsi yang berbeda menyangkut metode pemberian: apakah sebaiknya mereka memelihara metode pemberian tradisional atau merubahnya dengan metode modern. Metode tradisional yaitu Muslim memberikan zakat secara langsung kepada individu. ${ }^{18}$ Metode modern membiarkan Muslim untuk menggunakan sarana lembaga zakat.

\footnotetext{
${ }^{16}$ Amy Singer, Charity in Islamic Society, (Cambridge: Cambridge University Press, 2010).

${ }^{17}$ Arskal Salim, "The Influential Legacy of Dutch Islamic Policy on the Formation of Zakat (AlmsGiving) Law in Modern Indonesia," Pacific Rim Law \& Policy Journal, Vol 15, No 3, (2008), 683-701.

18 S.J. Gilani, (1987). "The Qur'an on Charitable Giving and Contemporary Social Values," Journal of Reserarch in Islamic Economics, Vol 3, No 1, (1987), 63-72.
}

374 al-Maslahah: - Volume 12 Nomor 2 Oktober 2016 
Terdapat pandangan yang berbeda mempertanyakan efektivitas metode pemberian langsung. Metwally bersikukuh bantuan temporer bagi yang lapar, haus, dan membutuhkan pakaian barangkali tidak perlu apabila Muslim Indonesia merencanakan program jangka panjang pengentasan kemiskinan sebagai sebuah prioritas. ${ }^{19}$ Menurut Metwally, pembayaran zakat, baik fitrah maupun maal, harus melalui lembaga-lembaga karitas lokal sebagai intermediasi antara pemberi dan penerima. Beberapa peneliti yakin pergeseran dari metode tradisional ke modern akan mengurangi kemiskinan secara lebih efektif. The Public Interest Research Advocacy Center, suatu organisasi non-pemerintah, memperkirakan potensi zakat nasional senilai 14 trilun rupiah. ${ }^{20}$ Selanjutnya, melebihi angka ini adalah kombinasi zakat dan infaq serta shadaqah berpotensi menghimpun 19 triliun rupiah setahun yang dapat digunakan untuk membantu yang membutuhkan. ${ }^{21}$

Perubahan metode berdampak pada tingginya angka pengumpulan karitas. Harian Pikiran Rakyat mendokumentasikan Dompet Duafa (DD), sebuah yayasan karitas di Jawa Barat, yang telah menerima kenaikan 10 persen dana zakat dari tahun 2009 hingga 2010. DD mengumpulkan zakat and infaq senilai 3.5 milyar rupiah sampai Oktober 2010. Sementara Badan Amil Zakat (BAZ) Banten, yaitu yayasan semi-pemerintah, juga menerima dana 3 milyar rupiah sampai Oktober 2010. Dana kedua lembaga ini diperoleh bukan hanya dari zakat tetapi juga dari infaq dan sadaqah perorangan. ${ }^{22}$ Amrullah melaporkan di akhir 2010, Bait alMaal Aceh menerima 5.4 milyar rupiah, dibanding tahun sebelumnya, yaitu 3.6 milyar rupiah. ${ }^{23}$

${ }^{19}$ M.M. Metwally, "Economic Consequences of Applying Islamic Principles in Muslim Societies," International Journal of Social Economics, Vol 24, No 7, (1999), 941-957.

${ }^{20}$ Public Interest Research \& Advocacy Center (PIRAC), Investing in Ourselves: Giving and Fund Raising in Indonesia, (Metro Manila: East Axis Creative, 2004).

21 "Republic of Indonesia Needs," "Indonesia Needs More Philanthropy" The Jakarta Post. Retrieved from www.thejakartapost.com 2 Novemver 2007.

22 "The Lack of Zakat," The Lack of Zakat Management, Pikiran Rakyat. Retrieved from http://newspaper.pikiran-rakyat.com/, 3 July 2011.

${ }^{23}$ Amrullah, Bait al maal Aceh and zakat, Serambi Indonesia, Friday 15, 2012. 
Sejumlah literatur dalam bahasan ini mendiskusikan banyak negara Islam menganggap zakat sebagai salah satu metode untuk menciptakan kesejahteraan sosial Islam. Beberapa negara Islam sedang mencoba mendirikan lembaga yang dikenal Bait al-Maal untuk mengumpulkan zakat. Muslim dapat menyerahkan zakatnya ke lembaga ini, tetapi mereka tetap mempunyai opsi lain untuk memberikan zakat mereka secara langsung kepada yang berhak, seperti yatim piatu atau masjid dan organisasi-organisasi yang berwenang mendistribusikan zakat.

Sejauh menggali data sekunder, peneliti ini tidak menemukan bukti keterkaitan antara pembayaran zakat dan pelaksanaan shalat atau angka-angka statistik mengenai keinginan individu-individu Muslim Indonesia dalam memberikan zakat mereka kepada perorangan atau lembaga. Namun, PIRAC (2007) melaporkan sekitar 94 persen Muslim Indonesian adalah pembayar zakat diatas rata-rata khususnya bagi mereka dengan pendidikan tinggi. Angka ini lebih tinggi dibanding negara mana saja di dunia Islam. Powell (2011) berhipotesa terdapat korelasi antara kenaikan income dengan tingginya angka partisipasi membayar zakat, juga perhatian yang tinggi dari pemerintah untuk meregulasi zakat kepada masyarakat dapat membantu meningkatkan jumlah pemberian. ${ }^{24}$

\section{Metode Penelitian}

Survey yang bersifat self-administered (dapat diakses dan dikerjakan sendiri) didesain dan disebarkan via Internet untuk mengumpulkan informasi dari para dosen dan pegawai administrasi UIN Sunan Kalijaga. Pertanyaan-pertanyaan penelitian adalah sama untuk semua responden, dan tidak ada klasifikasi kelompok. Setiap responden mendapatkan 19 pertanyaan. Kuesioner penelitian terdiri dari dua kategori: pertama adalah demografi. Pertanyaan satu hingga tujuh meminta informasi dari responden, seperti jenis gender, umur, status perkawinan,

24 R. Powell, Zakat: Drawing Insights for Legal Theory and Economic Policy from Islamic Jurisprudence. Retrieved from http://ssrn.com/abstract=1351024, !3 Januari 2011.

376 al-Maslahah: - Volume 12 Nomor 2 Oktober 2016 
jumlah keluarga, level pendidikan, level income, dan asal daerah. Kedua mencakup jenis perilaku responden dalam membayar zakat fitrah and maal. Secara khusus, pertanyaan delapan hingga 19 menyoal kehadiran di masjid, percaya wajibnya zakat fitrah dan maal, jumlah rupiah yang dibayar sebagai zakat fitrah dan maal selama Ramadan, metode pemberian, dan alasan memberi zakat fitrah dan maal.

\section{Sampling}

Penelitian ini merekrut para dosen yang sedang mengajar di UIN Sunan Kalijaga serta pegawai administrasi. Di kampus ini, terdapat kurang-lebih 498 Guru Besar, Lektor Kepala, Lektor, dan Asisten Ahli yang mengajar di sembilan fakultas dan puluhan jurusan. E-mail akun responden yang valid telah peneliti peroleh, dan terdapat 150 dosen dan 50 tenaga administrasi yang dapat dihubungi dan total terdapat 95 civitas akademika yang mengisi kuesioner yang peneliti ini sebarkan. Kuesioner telah dikirimkan secara elektronik via layanan Survey G-Mail yang dihubungkan dengan e-mail ke responden.

\section{Alat Analisis Data}

SPSS 21.0 telah digunakan untuk menganalisis data yang berasal dari responden. Sarana analisis statistik termasuk Pearson correlation coefficient digunakan untuk mengevaluasi hubungan antara pasangan-pasangan variabel ordinal dan mengevaluasi tingkat signifikansi dari hubungan-hubungan tersebut. Juga, peneliti ini telah menggunakan tes Chisquare untuk mengevaluasi tingkat signifikansi dari distribusi frekuensi untuk pasanganpasangan variabel ordinal dan untuk data kategori.

\section{Hasil}

Pertanyaan-pertanyaan yang ditanyakan dalam penelitian ini adalah: "Bagaimana Saudara membayar zakat fitrah?" dan "Bagaimana Saudara membayar zakat maal?" Responden dapat memilih lebih dari satu jawaban, dan jawaban-jawabannya termasuk institusi-institusi zakat, masjid, dan perorangan. Berkaitan dengan zakat fitrah, 54 responden mengatakan bahwa mereka membayar zakat fitrah ke masjid, 40 responden memberikan zakat 
mereka secara langsung kepada orang-orang miskin, diikuti dengan 20 responden memberikan zakat mereka kepada institusi-institusi zakat. Kebalikannya untuk zakat maal, 45 responden memberikan zakat mereka secara langsung kepada kaum miskin, diikuti oleh 25 respondent yang memberikan zakat mereka ke masjid-masjid. Demikian juga 10 responden menyalurkan zakat maal mereka ke panti-panti asuhan dan lembaga-lembaga pendidikan, selanjutnya delapan responden menunaikan zakat maal untuk organisasi-organisasi amal. Karakteristik pemberian zakat dalam penelitian adalah pemberian ke masjid-masjid dan pemberian langsung kepada orang-orang miskin adalah yang paling banyak dipilih oleh civitas akademika UIN Sunan Kalijaga. Hal ini mengindikasikan bahwa para responden cenderung bertahan dengan cara-cara tradisional dalam memberi, yaitu kepada individu-individu miskin atau ke masjidmasjid.

Pertanyaan-pertanyaan penelitian berkisar pada alasan-alasan responden untuk memberi, apakah kepada orang per-orang secara langsung atau ke lembaga-lembaga keagamaan atau amal. Ringkasnya, pertanyaan-pertanyaan dalam survey berbunyi: "Mengapa Saudara memberikan zakat fitrah atau maal secara langsung kepada individu-individu?" dan "Mengapa Saudara berikan zakat fitrah dan maal ke lembaga-lembaga keagamaan atau amal?" Satu atau beberapa jawaban responden dapat diberikan ke tiap-tiap pertanyaan. Diantara 95 responden yang menjawab, 55 responden mengatakan bahwa mereka memberikan zakat fitrah dan maal mereka secara langsung ke individu-individu karena mereka menyaksikan ada orang-orang yang membutuhkan dalam masyarakat, sementara 40 responden telah memberikan zakat mereka ke lembaga-lembaga keagamaan, pendidikan, atau amal karena mereka percaya lembaga-lembaga ini membantu dan bekerja untuk kemaslahatan publik. Untuk memberi kepada individu-individu, 12 responden memberikan alasan bahwa mereka tidak mempercayai lembaga-lembaga keagamaan maupun zakat.

\section{Interpretasi}

Metode pemberian zakat secara tradisional, seperti memberikan langsung kepada orang perorang dan institusi-institusi keagamaan, seperti masjid lebih banyak dipilih dan 
disukai oleh para responden. Tampaknya lebih dari setengah responden memberikan zakat mereka ke masjid-masjid daripada yayasan-yayasan amal. Secara tradisional, Muslim telah berdonasi ke masjid-masjid dengan dua alasan: pertama, masjid adalah institusi yang dapat ditemukan dimana-mana dan dominan dalam komunitas Muslim. Karena itu, kaum Muslim lebih teringat masjid apabila mau menyalurkan zakat. Contohnya, mereka menunaikan shalat ied di akhir Ramadan sekaligus membayar zakat fitrah dan maal pada waktu bersamaan. Kedua, pemberian zakat ke masjid-masjid barangkali disukai karena responden kurang mempercayai yayasan-yayasan baru yang mereka jumpai. Duabelas responden tidak mempercayai lembaga-lembaga zakat. Selain masjid, kebiasaan memberikan kepada individu lebih kuat daripada memberikan ke panti-panti asuhan, institusi-institusi pendidikan dalam bentuk beasiswa, lembaga-lembaga zakat, organisasi-organisasi amal dan panti-panti tunawisma. Hampir setengah responden yang termasuk dalam kategori pemberi ke individu dan yayasan telah memberikan zakat mereka secara langsung kepada orang-orang miskin. Surah al-Taubah telah menempatkan orang-orang miskin sebagai salah satu kategori mustahiq.

Hasil penelitian ini menunjukkan bahwa perempuan lebih berkeinginan untuk menunaikan zakat mereka ke lembaga dan yayasan daripada laki-laki. Sekarang ini banyak perempuan yang berprofesi sebagai tenaga pengajar di jurusan-jurusan non-agama dibandingkan dengan jurusan-jurusan agama. Data mengenai demografi ini tentang peran perempuan sebagai dosen memang tidak menjadi bagian investigasi dalam penelitian ini. Penelitian lanjutan hendaknya dapat mengeksplor aspek-aspek perbedaan lain yang mengontraskan antara laki-laki dan perempuan sebagai muzakki. Kenyataannya bahwa banyak perempuan yang bergolongan tinggi dalam karir mereka sebagai dosen merupakan salah satu aspek yang dapat diinvestigasi lebih lanjut tetapi tidak ditemukan dalam penelitian ini. Namun, perempuan kini banyak terlibat dalam filantropi dibanding pada masa dahulu. Caster (2010) melaporkan bahwa bertambahnya jumlah perempuan masa kini yang terlibat dalam aktivitas filantropi adalah terutama mereka yang berpendidikan tinggi, bertalenta, dan memiliki pengalaman profesional. Untuk alasan ini, peneliti ini berargumentasi bahwa dosen perempuan boleh jadi memberi lebih banyak ke yayasan-yayasan karena pengaruh tingkat pendidikan dan pengalaman mereka dalam masyarakat. 
Secara umum semakin lama seseorang bekerja ini akan berbanding lurus dengan pendapatan yang ia peroleh. Karena itu, responden yang lebih senior tentu memiliki penghasilan yang lebih besar daripada responden yang baru kerja. Hasil penelitian ini menunjukkan bahwa responden dengan gaji tinggi cenderung untuk membayar zakat fitrah maupun maal. Salah satu hasil yang mencengangkan adalah terdapat hubungan yang terbalik antara pergi ke masjid dan menunaikan zakat maal karena barangkali untuk kasus ini tidak ada peraturan khusus yang dipaksakan baik oleh lembaga-lembaga pengumpul zakat maal dan tidak ada sosialisasi tentang batas nishab dari zakat maal yang mesti dibayarkan. Akibatnya, beberapa muzakki dengan pendapatan rendah barangkali memberi lebih banyak daripada mereka dengan pendapatan tinggi. Apabila kita membandingkan kedua bentuk zakat ini, zakat fitrah itu jumlahnya lebih kecil dibandingkan zakat maal seusia dengan peraturan hukum Islam. Dalam membayar zakat fitrah, ukurannya adalah jumlah uang yang sama dengan harga belanja makan seseorang dalam sehari. Tetapi aturan zakat maal mengharuskan seorang Muslim untuk menyetor $2.5 \%$ dari total pendapatan atau aset yang ia miliki dalam setahun. Bagi yang sering shalat di masjid mereka harus diberikan perhatian yang banyak tentang aturan-aturan zakat maal, yang dalam penelitian ini terdapat korelasi negatif.

\section{Simpulan}

Berkaitan dengan zakat fitrah, sebagian besar responden ( 85 orang) memberikan zakat fitrah ke masjid-masjid, dan hampir setengah dari mereka memberikan zakat mereka secara langsung kepada orang-orang miskin; 20 responden telah memberikan zakat ke yayasanyayasan. Untuk zakat maal, hampir setengah responden telah memberikan zakat secara langsung kepada orang-orang miskin, dan hanya 25 responden telah memberikan zakat maal ke masjid-masjid. Terdapat 10 responden yang menyalurkan zakat maal mereka ke panti-panti asuhan, dan 10 responden memberikannya ke yayasan-yayasan pendidikan dalam bentuk beasiswa), diikuti oleh delapan responden yang membayar zakat maal untuk organisasiorganisasi kemanusiaan. Karakteristik-karakteristik donasi dan pemberian dalam penelitian ini menempatkan masjid-masjid dan orang-orang miskin sebagai penerima lebih sering dipilih 
oleh para dosen dan pegawai. Hal ini mengindikasikan bahwa para responden menyukai caracara pemberian yang tradisional, memilih untuk mendonasikan ke perorangan dan masjidmasjid.

\section{Daftar Pustaka}

Aji, M.S.N., Optimalisasi Potensi Zakat, Infaq dan Shadaqah, Tesis, (Surakarta: Universitas Sebelas Maret Surakarta, 2009).

Adnan, M.A., Accounting Treatment for Corporate Zakat: A Critical Review, International Journal of Islamic and Middle Eastern Finance and Management, Vol 2, No 1, (2011).

Alfitri, The Law of Zakat Management and Non-Governmental Zakat Collectors in Indonesia. International Journal of Not-for Profit Law, Vol 8, No 2, (2008).

Al-Qur'an al-Karim, The Qur'an: A New Translation, T. Khalidi (Trans.), (New York: Penguin Classics, 2010).

Amrullah, Bait al Maal Aceh and Zakat, Serambi Indonesia, Friday 15, 2012.

Benthall, J., Financial Worship: The Quranic Injunction to Alms-Giving, The Journal of the Royal Anthropological Institute, Vol 5, No 1, (2001).

Booth, W.C., Colomb, G.G., \& Williams, J.M., The Craft of Research, (Chicago: The University of Chicago Press, 2010).

Caster, J.J., A New Direction in Women's Philanthropy, Nonprofit and Voluntary Sector Quarterly, Vol 37, No 2, (2012).

Clark, G., Pakistan's Zakat System: A Policy Model for Developing Countries as a Means of Redistributing Income to the Elderly Poor, Social Thought, Vol 20, No 3/4, (2003).

Cohen, J., Statistical Power Analysis for the Behavioral Sciences, (New York: Academic Press, 1990).

Dean, H., \& Khan, Z., Muslim Perspectives on Welfare, Journal of Social Policy, Vol 26, No 2, (1999).

De Zayas, F.G. The Law and Philosophy of Zakat: The Islamic Social Welfare System, (Damascus: Al-Jadidah Printing Press, 1962).

Doa, M.D., Zakat under the State Management. Jakarta: Nuansa Madani, 2007). 
DePoy, E., \& Gitlin, L.N. (2007). Introduction to Research: Understanding and Applying Multiple Strategies, (St. Louis, MO: Elsevier Mosby, 2007).

Fox, W., Social Statistics, (Bellevue, WA: MicroCase Corporation, 2000).

Geoffrey, M., DeMatteo, D., \& Festinger, D., Essentials of Research Design and Methodology. Hoboken, N.J.: John Willey \& Sons, 2007).

Gilani, S.J., The Qur'an on Charitable Giving and Contemporary Social Values, Journal of Reserarch in Islamic Economics, Vol 3, No 1, (1987).

Glesne, C., Becoming Qualitative Researchers: An Introduction, (Boston: Pearson, 2010).

Hartatik, Emi, "Analisis Praktik Pendistribusian Zakat Produktif Pada Badan Amil Zakat," Laporan Penelitian, 2015.

Hinkle, D.E., Wiersma, W., \& Jurs, S.G., Applied Statistics for the Behavioral Sciences, (Boston: Houghton Mifflin Company, 2003).

Hourani, A., A History of the Arab Peoples, (Cambridge: Harvard University Press, 1993).

Ibrahim, B.L., Philanthropy: A New Concept in the Arab World, Daily News Egypt, 2011.

Khairah, I., Evaluasi Kinerja Zakat: Studi Kasus Manajemen Evaluasi di Rumah Zakat Cabang Yogyakarta), Skripsi, (Yogyakarta: UIN Sunan Kalijaga, 2011).

Kodir, F.A., Zakat Funds and Female Empowerment for Social Transformation. In Hamid Abidin (Ed.), Reinterpretation of Effective Use of Zakat, Infaq and Shadaqah, (Jakarta: Piramedia, 2006).

Mas'udi, M.F., Zakat: the Concept of Purified Wealth. In B.M. Rachman (Ed.), Contextualization of Islamic Doctrines in History, (Jakarta: Paramadina, 1997).

Metwally, M.M. (1999). Economic Consequences of Applying Islamic Principles in Muslim Societies. International Journal of Social Economics, Vol 24, No 7, (1999).

Padgett, D.K., Qualitative Methods in Social Work Research, (Los Angeles, CA: Sage, 2010).

Pagano, R.R., Understanding Statistics in the Behavioral Sciences, (Belmont, CA: Wadsworth, 2003).

Payton, R.L., \& Moody, M.P., Understanding Philanthropy: Its Meaning and Mission, (Indianapolis: Indiana University Press, 2010). 
Powell, R., Zakat: Drawing Insights for Legal Theory and EconomicPpolicy from Islamic Jurisprudence. Retrieved from http://ssrn.com/abstract=1351024, 2011.

Public Interest Research \& Advocacy Center, . Investing in Ourselves: Giving and Fund Raising in Indonesia, (Metro Manila: East Axis Creative, 2004).

"Republic of Indonesia Needs," Indonesia Needs More Philanthropy, The Jakarta Post, Retrieved from www.thejakartapost.com, 2007.

Riyadi, R., Kebijakan yang Wajib, Republika. Retrieved December 2, 2008 from http://www.republika.cor.id, 2007.

Salim, A., The Influential Legacy of Dutch Islamic Policy on the Formation of Zakat (AlmsGiving) Law in Modern Indonesia, Pacific Rim Law \& Policy Journal, Vol 15, No 3, (2008).

Saifuddin, Optimalisasi Distribusi Dana Zakat: Upaya Distribusi Kekayaan: Studi Terhadap UU No. 23 Tahun 2011 Tentang Pengelolaan Zakat. Jurnal Az Zarqa, Vol. 5, No 2, (2013).

Singer, A., Charity in Islamic Society. Cambridge: Cambridge University Press, 2010.

"The Lack of Zakat," The Lack of Zakat Management, Pikiran Rakyat. Retrieved from http://newspaper.pikiran-rakyat.com/, 2011.

Visser, H., Islamic Finance Principles and Practice, (Northampton, MA: Edward Elgar Publishing, 2011).

Weiss, H., Reorganising Social Welfare Among Muslims: Islamic Voluntarism and Other Forms of Communal Support in Northern Ghana, Journal of Religion in Africa, Vol 32, No 1, (2004).

Wilson, R., The Development of Islamic Economics: Theory and Practice. In S. TajiFarouki \& B.M. Sufi (Eds.), Islamic Thought in the Twentieth Century. (New York: St Martin's Press, 2006).

Yegidis, B.L., \& Weinbach, R.W., Research Method for Social Workers, (Boston: Allyn and Bacon, 2006).

"Zakat Tragedy," Zakat Tragedy in Pasuruan: A Portrait of Poverty. Retrieved from www.kompas.com, 2010. 